\title{
DE ZOGENAAMDE SAMENGESTELDE VERKLARING
}

\author{
door Drs. L..J. H. Ronzen
}

\section{Inleiding}

Het Nederlands Instituut van Registeraccomnants heefi d.d. 23 juni 1976 een ont werp meningsuiting, getiteld: ..DC inhoud van de accountansverklaring bij de jaarrekening van ondememingen met continuïteisproblemen" doen verschij. nen.

In het onwerp word een aantal situaties onderscheiden, athankelijk ran:

het oordeel over de continuiteit (niet verbroken - verbroken - onzeker),

degene die het oordeel velt (verantwoordingsplichtige of accountant) en

de voor de jaarekening gekozen wataderingsbasis (continuïteit licquidatie).

Voor de situaties, watin de accountant onzeker is of de continuinteit is verbroken en de jaarekening op continuteitsbasis is opgesteld, wordt in het ontwerp) (de gevallen 2 en 4) de volgende ,..samengestelde" verklaring als ,beste oplossing" aanberolen.

,Wij hebben de jaarrekening 19.. van de vennootschap X gecontroleerd. Uit deze jaarrekening en het verslag van de directie blijkt onzekerheid over het voortbestan van de ondememing. Wij kunnen ons met de hieromtrent verstrekte in. formatie verenigen

De in de jaarekening loegepaste watarderingsgrondslagen zijn bepaald op basis van de veronderstelling dall de onderneming zal kunnen voortbestaan. Bij dit uit. gangspunt zijn wij op grond van ons onderzoek van oordeel dat de jarrekening een getrouw beeld geefi van de grootle en samenstelling van het vermogen van de vermootschal) op 31 december 19. en van het resultat over 19.

Indien de onderneming echer zal moeten worden beëindigd zijn de gekozen waarderingsgrondslagen niet toepasselijk en is het opnemen van licpuidatiever plichtingen ten onrechte achterwege gebleven. Alsclan rijn wij van oordeel dat de jaarrekening niet een getrouw bockl geeft van de grootte en samenstelling van het vermogen van de remootschap op 31 december $19 . . . "$

Het onderwerp) is gepubliceerd en het NIVRA bestum noem als roomanamste aanleiding een door hem vastgesteld misverstand in het verkeer over de inter. pretatie van de beroepsregelen.

Voorts is de nitwerking zo origine el, dat een loetsing aan de bestaande grond. slagen van de GBR moet beslissen over een wijziging of handhaving van die grondslagen en in elk geval kan die loetsing het inzicht datin verdiepen. Een openbare discussie over het onwerp is daarom, van de aanvang al, ten zeerste gewenst. Het navolgende is een poging daartoe bij te dragen.

\section{De aanleiding voor het ontwerp}

In hel voorwoord van het NIVRA bestuur worden a wee molieven roor de hernieuwde studie genoemd:

a. Verschil in opvatuing en praklijk over de inhoud van de verklaring bij conti. nuiteitsproblemen.

De gewenstheid ran een communis opinio en een unifon toepassing kan worden onderscheven. doch beslist nict over een bepalde inhoud. 
b. Doorslaggevend lijkt de volgende overweging van het Bestuur: "Ernstiger is evenwel, dat in de praklijk de verklaring van oordeelonthouding als een afkeu. rende verklaring word ervaren (. . L"

Tegen deze overweging richten zich mijn eerste bezwallen.

In de cerste plaats wordt de\% bewering niet gestadel door de resultaten van een verant woord opinie-onderzoek, althans blijkt darran niets. Mijn eigen prak. tijkervaring wijst niet in die richting. Wel kan het voorkomen, dat een verant. woordingsplichtige, die gerekend had op een goedkeurende verklaring, tich emo tioneel of om taktische redenen in die geest uitlat, doch dit behoefi de accoun tant niet uit zijn evenwicht te brengen. Het verschil tussen een oordeel onthouding en een afkeuring (resp. goedkeuring) moet iedere verstandige leek zijn duidelijk te maken. Bovendien: zijn wij vergeten, dat de introductie van de oor deelonthouding juist een tegemoetkoming was aan een gegroeide praktijk.'

In de tweede platats mag het verwondering wekken, dat niet mede en eersi! wordt overwogen of een geconstateerde "ervaring" wan het publiek op reële gronden steunt. Zo dat niet het geval is, moet het gestelde probleem worden op. gelost door een vakkundige voorlichting van de indlividuele accountants ain hun cliënten, en/of door publieke voorlichting van het NIVRA. Een klakkeloos volgen van een verkeerde opwatting bij het publiek is bezwarlijk te rijmen met de onafhankelijkheid en met de zelfstandigheid van het oordeel, die de wezenskenmer. ken zijn van de publieke functie.

In de derde plats richt zich het onder b geciteerde tegen de oordeelonthou ding als zodanig, d.w.z. niet alleen in verband mee continuïteitsproblemen. Er is trouwens geen redelijk argument aan te voeren voor de stelling, dat de oordeel onthouding alléen als een alkeurende verklaring .wordt ervaren”, indien zij in verband met continuile eitsproblemen wordt gehanteerd.

Aanvaarding van de voorstellen van de werkgroep zou derhalve logischerwijze voeren tor een integrale verianging van de verklaring van oordeelonthouding door de rgn. samengestelde verklaring.

\section{De aard van de „samengestelde" verklaring}

Wezen en kenmerk van de "samengestelde" verklaring worden aalkundig nier gedekt door de term "simengesteld".

"Samenstel” duidt op een eenheid (vergelijk artikel 17 GBR: de jaarrekening als "het samenstel van bescheiden"), alsof van éen verklaring sprake zou zijn.

In werkelijkheid wordt een tupe-troudige verklaring voorgesteld: omtrem dezelf. de verantwoording zouden twee verklaringen worden verstrekt.

Wil men niettemin tussen die twee verklaringen een verband leggen en via dat verband (negatie tegenover aflirmatie van continuiteitsverbreking), toch beslui ten tot de eenheid van één verklaring, dan moet gezegd worden, dat die verkla ring raadselachtig is als orakelatal. $\mathrm{Zij}$ is in dic eenheid in de letterlijke betekenis dubbelzinnig.

\section{Strijd met de gedrags- en beroepsregelen (GBR)}

De werkgroep rapporteert:

„Nader valt te onderzoeken of de voorgestelde tekst van de accountantsverkla 
ring zich verdratagt met antikel 12, lid 2, van de GBR."

Het kom mij voor, dat een nader onderzoek geheel overbodig is. De strijdig. heid is evident:

a. De GBR opent slechts de mogelijkheid to het afgeven van éen der daarin genoemde verklaringen bij elke verantwoording (als geheel'). 1.w. , hetzij" een goed. keuring (al of niet onder voorbehoud), ,hetzij" een atkeuring, ,hetzij" een oordeel onthouding (artikel 12, lecten 1 en 2).

De ,samengestelde" verklaring bevalt wee verklaringen: een goedkeuring en cen afkeuring.

b. Die twee rerklaringen zijn elk roor zich stellig, doch spreken elkaar lijnrecht tegen (zij moeten betrekking hebben op de verantwoording ,als geheel"!). De ,samengestelde" verklaring als eenheid opgevat - is in de hoogst denkbare mate "dubbetzinnig": zij is onzinnig.

c. De twee verklaningen bevalten elk een voorbehoud („Bij dit uitgangspunt ..." en .Indien ..."), waarbij niet worde voldaan aan:

1 het voorschrift van de bewoordingen, „onder voorbehoud ..." (artikel 14, lid 1. GBR:

2 het voorschrift, de draagwijde aan te geven (artikel 14, lid 1, GBR);

3 het voorschrift, dat het voorbehoud atu de strekking van de verklaring niet wezenlijk aflreuk mag doen (artikel 13, lid 2, GBR), hetgeen de twee verklaringen op de meest duidelijke wijze doen ten oprichte van elkaar.

Een ernstige leemte in het voorstel is dat niet wordt aangegeven, welke wijzigingen in de GBR noodzakelijk zouden zijn voor een introductie van de zgn. sa. mengestelde verklaring die, zoals ecrder betoogd, de verklaring van oordeelont. houding integral zou gaan vervangen, wil de bij het publiek gesignaleerde ver. warring met de afkeuring op de voorgestelde wijze ondervangen worden.

\section{Toepassing buiten de continuitteitsproblemen}

Hiervóór heb ik betoogd, dat het voomanuste aangevoerde argument voor de toepassing van de zgn. samengestelde verklaring algemeen geldend is en de consequentie heeft van een vervanging van elke oordeelonthouding door een twee. voudige verklaring.

Enkele voorbeelden:

a. Onzekerheid over subsidies.

De iweevoudige verklaring zou luiden:

„Bij het uitgangspunt dat de overheid het exploitatie tekort volledig zal subsidië ren zijn wij op grond wan ons onderzoek van oordeel, dat de jaarrekening een ge trouw beeld geeft (enz.).

Indien echter wordt verondersteld, dat de overheid een aanmer kelijk deel van het tekort niet zal subsidiëren, alsdan zijn wij van oordeel dat de jaarrekening niet een getrouw beeld geeft (enz).."

$b$. Onzekerheid over de grootte van posten van de jaarrekening (omzet, waarde ran activa, noodzakelijke roorzieningen enz.).

Zou bij: de accountan in onzekerheid verkeren over de hoogte van een ge. uroffen voorziening, dan zou die twee voudige verklaring luiden:

"Bij het uitgangspunt dat de voorziening voldoende is, zijn wij op grond van ons onderzoek van oordeel, dat de jaarrekening een getrouw beeld geeft (enz.). Indien 
echter wordt verondersteld dat de voorziening onvoldoende is, alsdan zijn wij van oordeel dat de jaarrekening niet een getrouw beeld geeft (enz.)."

De duisterheid en irrelevantie van de twee voudige verklaring is in de voorbeelden nog opvallender.

Toch zou hier mer evenveel reden beweerd kumnen worden (cit. werkgroep): "dat door de accountant precies wordt gezegd wat de belanghebbende wil weten", en: „Van de accountant mag (.. .) worden verlangd, dat hij uiteenzet hoe hij tegen de situatie aankijkt".

Veronachtzaamd wordt, dat het verkeer wil weten of de verantwoording juist is en dat een oordeel van de accountant betrekking heeft op de verantwoording als geheel.

Dat is geheel iets anders dan een nauwkeurige uiteenzetting van de situatie, waar. in het bedrijf zich volgens de accountant bevindt.

Die uiteenzetting is in eerste instantie bestend voor de verantwoordingsplich. tige en - zo nodig en praktisch mogelijk - voor een beperkt verkeer; zij geschiedt binnen het kader van de adviserende functie en wel mondeling. waardoor zij niet het karakter heeft van een verklaring. (De verklaring immers is in de nieuwe beroeps. regelen (GBR) uitdrukkelijk beperk 1 to een schriftelifke mededeling; diende die wijziging niet juist ten behoeve van een onbelemmerde uitoefening van de advise. rende functie?). Binnen dat kader kan de accountant eventucel mededelen, of hij bij opheffing van de onzekerheid over de continuiteit al of niet in staat is een stel. lige (goedkeurende of afkeurende) verklaring al te geven.

\section{Zelfstandigheid van het oordeel}

Een ander bezwaar betrefi de betekenis die in dit verband systematisch (zie de tabel) wordt toegekend atan het standpunt van de verantwoordingsplichtige voor de vorming van het oordeel van de accountant.

De uitdrukkelijke verwijzing in het model van de samengestelde verklaring naar de ,informatie" van de verantwoordingsplichtige (blz.. 7, le kolom) is m.i. ge. heel misplaatst, althans overbodig (zie artikelen 12, lid 1 en 26, lid 2, GBR).

\section{Onjuiste uitwerking van de variabelen}

Zijdelings merk ik op dat de werkgroep zonder meer voorbij gat aan mijn betoog in MAB jan. 1976, volgens welke in de gevallen 3, 5 en 6 (de accountant is zeker van een verbreking van de continuiteil, doch cle jaarrekening is vastgesteld op continuiteitsbasis) sprake is van een niet-valide verantwoording (C i.p.v. L), waarbij geen enkele verklaring kan worden verstrekt, terwijl zij het door mij bestreden standpunt van Frielink overneem, dan de alkeuring prevaleert boven de oordeel. onthouding (zie het model van de twee voudige verklaring).')

Nadat als probleem is gesteld, dat het publiek de oordeelonthouding ervaart als een alkeuring, wordt in een annal gevallen stilzwijgend de oordeelonthouding vervangen door de alkeuring!

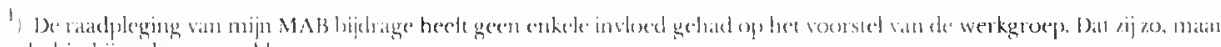
worde hicolij wel rastgestedt
} 


\section{Onvolledige opsomming der variabelen}

Het ontwerp laat buiten beschouwing de gevallen waarin de accountant zonder continuïteitsproblemen tot een afkeuring zou zijn gekomen.

De twee voudige verklaring wordt nu zo mogelijk nog raadselachtiger:

„Bij het uitgangspunt dat de onderneming zal kunnen voortbestaan, zijn wij van oordeel dat de jaarrekening niet een getrouw beeld geeft (enz.), omdat (enz.).

Ook al zouden onze bezwaren genoemd in de eerste alinea zijn opgeheven, zijn wij, indien wordt uitgegaan van de veronderstelling dat de onderneming zal moeten worden beëindigd, niettemin van oordeel dat de jaarrekening niet een ge. trouw beeld geeft (enz.), omdat (enz.)",

of (althans redaktioneel duidelijker):

„Bij het uitgangspunt dat de onderneming zal moeten worden beëindigd, zijn wij van oordeel dat de jaarrekening niet een getrouw beeld geeft (enz.).

Indien de onderneming zal kunnen voortbestaan, zijn wij niettemin van oordeel, dat de jaarrekening niet een getrouw beeld geeft (enz.), omdat (enz.)."

Hier raken wij de werkelijke moeilijkheid bij de toepassing van de oordeelont. houding: betekent die dat, behalve de met name te noemen onzekerheden, de verantwoording juist is?

\section{De oordeelonthouding betreft de verantwoording als geheel}

Met Frielink ben ik van oordeel, dat een toevoeging „overigens juist” of „overi. gens is ons van enige onjuistheid niet gebleken" in de verklaring van oordeelont. houding niet past. ${ }^{2}$ )

De onthouding betreft de verantwoording als geheel en laat de vraag of, zonder de genoemde onzekerheden, de verantwoording zou zijn goedgekeurd of afgekeurd, volledig onbeantwoord. Eerst wanneer de onzekerheden zijn opgeheven kan alsnog een stellige (goedkeurende of afkeurende) verklaring volgen.

Een en ander kan onderwerp uitmaken van de mondelinge „uiteenzetting" van de accountant ,hoe hij tegen de situatie aankijkt".

De verklaring van oordeelonthouding betekent, dat de controle-arbeid niet (of nog niet) heeft gevoerd tot een vervulling van de functie, t.w. de bijdrage tot de zekerheid voor het verkeer dat de verantwoording juist is. Op zichzelf een onge. rijmdheid, maar wij hebben die vorm van de ,verklaring” nu eenmaal aanvaard. ${ }^{3}$ )

Een oordeelonthouding is een voor het verkeer bestemde mededeling dat de accountant géén oordeel heeft over de juistheid van de verantwoording als geheel. Elke afwijking van dit beginsel (en de zgn. samengestelde verklaring leidt daar onherroepelijk toe) betekent alleen maar dat de lappendeken nog bonter, de functievervulling voor het publiek nog mysterieuzer wordt.

\section{Samenvatting}

1 Eerst worde de bewering dat in het verkeer sprake is van verwarring van de oordeelonthouding met de afkeuring, getoetst aan de werkelijkheid.

2 Zo die verwarring blijkt te bestaan, ware te overwegen of die verwarring op goede gronden berust.

\footnotetext{
2) MAB mei 1976, blz. 290 .

In her MAB mei 1976 heb ik de invoering van de oordeelonthouding een verarming van de openbare lunctie genoemo en aanbevolen er een spaarzaain gebruik van te maken.
} 
3 Zo niet, dan berade men zich over een deskundige, individuele en algemene voorlichting.

4 De ,samengestelde" verklaring maakt de oordeelonthouding overbodig en is buitendien in strijd met vrijwel alle bepalingen in het hoofdstuk „Verklaringen" van de GBR, en met zijn grondslagen.

5 Wijziging van de GBR volgens de voorstellen van de werkgroep kan een eventuele verwarring bij het publiek slechts vergroten.

augustus 1976 